\title{
Título do blogue: ana vidigal
}

URL: http://anavidigal.blogspot.com/

Cristina Néry

\section{(2) OpenEdition \\ Journals}

Edição electrónica

URL: http://journals.openedition.org/rccs/3694

DOI: $10.4000 /$ rccs.3694

ISSN: 2182-7435

\section{Editora}

Centro de Estudos Sociais da Universidade de Coimbra

\section{Edição impressa}

Data de publição: 1 junho 2010

Paginação: 225

ISSN: 0254-1106

\section{Refêrencia eletrónica}

Cristina Néry, «Título do blogue: ana vidigal », Revista Crítica de Ciências Sociais [Online], 89 | 2010, posto online no dia 01 outubro 2012, consultado o 15 setembro 2020. URL : http:// journals.openedition.org/rccs/3694 


\section{Espaço Virtual}

\section{Título do blogue: ana vidigal URL: http://anavidigal.blogspot.com/}

Existe desde 2007 e constitui-se como um arquivo pessoal e actualizado do trabalho de 30 décadas da artista plástica Ana Vidigal. Afirma: a "pintura é tudo o que se cola". O processo é estabelecido assim pela artista como um regime de reciclagem de elementos que passa pelo uso de objectos da sua infância ou elementos característicos da cultura dos anos sessenta. O blogue é gerido pela própria, para que não fique nada por ver, como um depósito de narrativas do seu trabalho. Ana Vidigal convoca a experiência da memória entre a intensidade pessoal e a intensidade do mundo. Através do blogue, vemos como a artista se apropria de imagéticas populares e familiares, figuras de cartoons, padrões de costura, vinil, revistas e geometrias muitas sobre que se debruça com toda a atenção e detalhe. Os objectos que cria colocam-nos no campo do arbitrário. Digo: é sempre assustador trabalhar notas pessoais. Não é bem sair do silêncio. É trazer a paisagem de dentro delas até ao epicentro da alucinação para o lado do corpo. Os trabalhos de Vidigal são uma plataforma de rupturas com o corpo martirizado da história tradicional, onde a artista plástica disponibiliza o seu confronto, também e sobretudo como mulher, com lugares da memória e de pertença. Em instalações pontuadas por uma comoção enigmática, todas as pistas apontam para uma leitura subversiva das imagens que alteram a nossa percepção do mundo e as nossas relações. Interessa-lhe o processo, até porque nenhuma das suas obras se pode definir como produto final, antes precipitam a interacção da nossa imaginação. Aí reside o desengano, na escavação das coisas que nos são próximas, onde "o humor é uma tábua enorme de salvação”, afirma Vidigal.

\section{Cristina Néry}

\section{Título da página electrónica: feminist.com URL: http://www.feminist.com/}

feminist.com existe desde 1995 e constitui-se como uma comunidade online e uma organização sem fins lucrativos norte-americana que pretende promover a consciencialização, educação e, sobretudo, o activismo das mulheres. Este site disponibiliza um imenso arquivo actualizado de informações e recursos, aspirando a ser um "Google feminista", que aproxime mulheres, bem como as organizações que servem os seus interesses. Conta com cerca de vinte parceiros, como a Amnistia Internacional ou a Nobel Women's Initiative, cujas campanhas e actividades divulga. Enquanto arquivo, feminist.com abrange uma panóplia de temáticas (política, ciência e tecnologia, arte e cultura, imagem do corpo, educação, ambiente, família, saúde e sexualidade, raça e etnia, LGBT, media, história das mulheres e anti-violência, entre outros) apresentadas na forma de livros, artigos e links, funcionalmente agregadas por secções. Os artigos de opinião, as conversas com mulheres "inspiradoras" (escritoras, actrizes, 
políticas de sucesso) e a coluna "Ask Amy", assinada pela activista Amy Richardson desde 1995, marcam a fisionomia desta página electrónica. Destaque também para as recentes rubricas "raparigas e mulheres jovens" ("girls and young women") enunciando os sujeitos do futuro do feminismo, e "mulheres e paz", que promove pessoas e organizações que têm por objectivo a paz mundial. feminist.com tem ainda uma importante rubrica que pretende promover o acesso das mulheres ao mercado de trabalho: um directório de oportunidades de emprego e negócio dirigido a mulheres. Interessante e útil para investigadores/as, e, sobretudo, para a comunidade não-académica, é de lamentar a ausência de referências fora do mundo anglo-americano e alguma aspiração enciclopédica [canibalizadora que pode resultar em miopia]. 